2. Гаськевич О. В. Структура грунтового покриву Гологоро-Кременецького горбогір'я / О. В. Гаськевич, С. П. Позняк. - Львів : Вид. центр ЛНУ ім. І. Франка, 2007. - 208 с.

3. Гиляров М. С. Зоологический метод диагностики почв / М. С. Гиляров. - М. : Наука, 1965. - 278 с.

4. Гиляров М. С. Учет крупных почвенных беспозвоночных (мезофауна) / М. С. Гиляров // Методы почвенно-зоологических исследований. - М. : Наука, 1975. - С. 12-29.

5. Гиляров М. С. Зоологическая мелиорация почв / М. С. Гиляров // Природа. - 1976. - № 10. - С. 18-20.

6. Гиляров М. С. Биогеоценология и агроценология / М. С. Гиляров. - Пущино : Науч. центр биол. исследований АН СССР, 1980. - 16 с.

7. Гиляров М. С. Животные и почвообразование / М. С. Гиляров // Биология почв Северной Европы. - М. : Наука, 1988. - С. 7-16.

8. Жуков О. В. Біологічне різноманіття України. Дніпропетровська область. Дощові черв'яки (Lumbricidae) / О. В. Жуков, О. С. Пахомов, О. М. Кунах. - Дніпропетровськ : Вид-во Дніпропетр. нац. ун-ту, 2007 $371 \mathrm{c}$.

9. Іванців В. В. Структурно-функціональна організація комплексів грунтових олігохет західного регіону України / В. В. Іванців. - Луцьк : РВВ «Вежа» Волин. держ. ун-ту ім. Лесі Українки, 2007. - 400 с.

10. Пахомов О. Є. Функціональне різноманіття грунтової мезофауни заплавних степових лісів в умовах штучного забруднення середовища / О. Є. Пахомов, О. М. Кунах. - Дніпропетровськ : Вид-во Дніпропетр. нац. ун-ту, 2005. - 324 с.

11. Перель Т. С. Распространение и закономерности распределения дождевых червей фауны СССР / Т. С. Перель. - М. : Наука, 1979. - 272 с.

Иванцив Владимир, Бусленко Леся, Сидорчук Петр. Комплексы дождевых червей агробиоценозов Кременецкого кряжа. Экологический спектр комплексов дождевых червей Кременецкого кряжа позволяет охарактеризовать основные свойства почв. Видовой состав комплексов люмбрицид может варьировать в значительных пределах конкретного вида грунта. Наличие тех или иных видов дождевых червей в агробиоценозах обусловлено влиянием совокупности эдафических факторов. Важное значение в формировании комплекса люмбрицид в агробиоценозах обусловлено растениями. Ведь они выступают регуляторами эдафических факторов и формируют трофическую базу для сапромезофауны почв.

Ключевые слова: дождевые черви, люмбрициды, агробиоценозы, дерново-среднеподзолистые, светлосерые лесные, серые лесные, темно-серые оподзоленные почвы, черноземы оподзоленные, Кременецкий кряж.

Ivantsiv Volodymyr, Buslenko Lesia, Sydorchuk Petro. The Rainworm Complexes in Agrobiocenoses of Kremenets Ridge. Ecological spectrum of the rainworm complexes of Kremenets Ridge enables us to characterize main soil properties. Species composition of lumbricidae complexes may vary in the wide range of a specific soil type. The presence of some or other types of rainworms in agrobiocenoses is influenced by a number of edaphic factors. And significant role in formation of lumbricidae complexes in agrobiocenoses is played by plants. They regulate edaphic factors and form trophic level for the soil sapomesofauna.

Key words: rainworms, lumbricidae, agrobiocenoses, sod-medium textured podzolic soils, light-grey forest, light forest, dark-grey podzolic soils, podzolic chernozem soils, Kremenets Ridge.

Стаття надійшла до редколегії 26.02.2015 p.

УДК 298.2:502.211(477.43/.44)

\title{
Олександр Матвійчук
}

\section{Ретроспективна оцінка орнітофауни Подільського Побужжя}

У статті висвітлено результати вивчення сучасного видового складу авіфауни Подільського Побужжя. Упродовж 2000-2014 років у регіоні виявлено 243 види птахів. Під впливом антропогенного чинника 3 початку XX ст. 22 види зникли з меж досліджуваної території, 36 - змінили свій статус перебування на ній, а 21 вид зареєстровано тут уперше.

Ключові слова: орнітофауна, Подільське Побужжя, антропогенна трансформація, фауністичне походження, видовий склад.

(C) Матвійчук O., 2015 
Постановка наукової проблеми та ї̈ значення. Зростання кількості населення, інтенсифікація промислового та сільськогосподарського виробництва на Європейському континенті спричинює посилення тиску на природні екосистеми 3 подальшою їх трансформацією. При цьому відчутного впливу зазнає біотичний компонент, у тому числі й орнітофауна. Подолання наслідків техногенного пресингу на природні екосистеми можливе за умови розробки концепції збалансованого природокористування, що грунтується на результатах моніторингу сучасного стану екосистем та ретроспективного аналізу їх структурних змін. Авіфауна Поділля як потужного агропромислового регіону поза сумнівом зазнала відчутної трансформації. Саме тому ми здійснили спробу встановити характер змін, що відбулися у видовому складі орнітофауни регіону упродовж минулого століття, та з'ясувати iї сучасну видову структуру. Робота актуальна ще й тому, що з початку ХХ століття системні дослідження авіфауни регіону не проводилися. Найгрунтовніші наукові праці, що містять інформацію про видовий склад і топічні зв'язки орнітофауни Подільського Побужжя, датовані 1918-1935 роками.

Методи дослідження. Орнітофауну Подільського Побужжя ми вивчали упродовж 2000-2014 років на території Вінницької та Хмельницької областей. Протягом усіх сезонів указаного періоду були проведені облікові роботи в основних типах природних та антропогенних ландшафтів регіону. Обліки здійснювали маршрутним методом (лінійних трансект) [4]. Маршрути прокладали у кожному типі ландшафту так, щоб облікова смуга охоплювала якомога більшу площу біотопу і найповніше відображала різнорідні стації, що його формують.

Відносну чисельність птахів у біотопах характеризували відповідно до шкали бальних оцінок, яку запропонував А. П. Кузякін [2].

Для з'ясування видового складу сов застосовували маршрутний метод і метод голосової стимуляції через відтворення фонограм за допомогою переносного динаміка [4].

У зимовий період проводили обліки зимуючих водоплавних та навколоводних птахів на місцях їх скупчень, якими є незамерзалі ділянки акваторій поблизу ГЕС, ДРЕС, ТЕЦ, колекторів міських очисних споруд.

Усього за період досліджень за обліковими маршрутами пройдено 2846 км (1416 облікових годин).

Задля виявлення максимальної кількості представників авіфауни регіону, окрім візуальних спостережень, застосовували також відлов птахів за допомогою павутинних сіток, щоб окільцювати їх.

Систематичне положення та порядок розташування видів у цій роботі подано за Г. В. Фесенком та А. А. Бокотеєм [10]. Типи фауністичного походження птахів наведено за Б. К. Штегманом [12].

Виклад основного матеріалу та обгрунтування отриманих результатів дослідження. Аналіз літературних джерел та польові дослідження, проведені у 2000-2014 роках, дали підставу встановити перебування у межах Подільського Побужжя на початку XXI ст. 243-х видів птахів, що становить 58,4 \% загальної кількості видів авіфауни України. У систематичному аспекті виявлені види птахів належать до 19-ти рядів, 53-х родин і 132-х родів [10].

У басейні р. Південний Буг упродовж останніх 20 років ми виявили 200 видів птахів, а у верхів'ях річки в межах Хмельницької області В. О. Новак та Л. М. Новак [6] виявили ще 43 види птахів.

За статусом перебування у межах дослідженої території домінують гніздові (110 видів, 45,3\%) та осілі (50 видів, 20,6 \%) птахи. Транзитних птахів виявлено 42 види $(17,3 \%)$, зимуючих - 24 види $(9,9 \%)$ та зальотних -20 видів $(8,2 \%)$.

3і 169-ти видів осілих і гніздових перелітних птахів Подільського Побужжя найбільш поширені представники європейського типу фауни - 81 вид (47,9\%). Удвічі менше транспалеарктів - 44 види (26 \%). Сибірська фауна представлена 18 видами (10,7 \%), а середземноморська - 13 видами (7,7 \%). Участь птахів інших типів фауністичного походження у формуванні орнітоценозів Подільського Побужжя порівняно невисока: шість арктичних видів (3,6 \%), п'ять монгольських $(2,9$ \%) і по одному представнику тібетської та китайської фауни (по 0,6 \%).

Зважаючи на результати власних досліджень, а також літературні дані [6], можна стверджувати, що в дослідженому регіоні упродовж останніх двох десятиліть було виявлено 243 види. На початку ХХ ст. різні дослідники нараховували у тій самій місцевості 223 [11], 191 [1], 145 [8] і 149 [7] видів птахів.

Відомо, що одними 3 визначальних чинників у формуванні орнітофауни будь-якої території $\epsilon$ топічний і трофічний. Внаслідок докорінного перетворення території Поділля, спричиненого діяльністю людини, упродовж останніх 80-100 років фауна птахів цієї території зазнала суттєвих структурних та кількісних змін. 
Деякі види зникли з меж Поділля або змінили свій статус перебування. На противагу їм, певна кількість видів розширила свій гніздовий ареал, заселивши, зокрема й територію Вінницької та Хмельницької областей.

Порівнюючи списки птахів Подільського Побужжя, складені на початку минулого століття [1; 7; $8 ; 11], 3$ даними сучасних досліджень [3; 6], можна помітити істотну різницю у видовій структурі авіфауни та характері перебування окремих видів птахів у межах Вінницької та Хмельницької областей.

Так, порівняно стабільною залишилась чисельність і не відбулося змін у характері використання території для 186 видів птахів, що становить 70,2 \% загальної кількості видів птахів, виявлених у цьому регіоні упродовж XX - поч. XXI ст.

Зазначимо, що 22-х видів птахів, які виявили дослідники у 1918-1935 роках, наразі немає на теренах Подільського Побужжя. Водночас у цьому регіоні за останні 80-100 років 3'явилися представники 21-го виду.

Ще 36 видів птахів упродовж означеного вище періоду різним чином змінили свій статус перебування на території. Так, 17 гніздових перелітних та осілих видів нині трапляються лише під час зальотів або міграцій i, навпаки, для шести транзитних видів наразі виявлене гніздування на Поділлі. По одному виду птахів взаємно змінили свій статус із «зальотних» на «мігруючі»; два зальотні раніше види птахів нині $є$ гніздовими, а ще дев'ять видів почали регулярно зимувати.

Подібні процеси у пташиному компоненті Подільських екосистем відбулись під впливом цілої низки чинників. Сукупність зовнішніх впливів на птахів можна представити як дію трьох груп: абіотичного, біотичного та антропогенного походження.

Слід розуміти, що дія перших двох груп чинників переважно епізодична, тому не може глобально впливати на орнітофауну регіону, зумовлюючи відчутні зміни у ії видовій структурі та чисельності. Значно потужнішим є антропогенний фактор, і саме його дія спричинила деградацію природних екосистем, а відтак і їх орнітокомпонента.

Найуразливішою групою птахів за умови радикальної зміни ландшафтної структури місцевості $€$ стенотопні види. Передусім це стосується птахів-петрофілів, які тісно пов'язані з різноманітними скельними масивами. Активна розробка кар'єрів у місцях виходу на поверхню гранітів спричинила знищення потенційних місць гніздування Monticola saxatilis на Поділлі.

Швидкі темпи економічного зростання різних галузей народного господарства у першій половині XX ст. реалізувались переважно екстенсивним способом. Активно здійснювалися гідромеліоративні роботи, спрямовані, з одного боку, на осушення заболочених ділянок уздовж водотоків, 3 іншого - на формування систем штучних водойм: водосховищ, ставів тощо. Наслідками такої діяльності стали глибокі зміни структури природних гідроценозів, а відтак і їх орнітонаселення. Через деградацію водно-болотних ландшафтів зникли Porzana pusilla, що раніше гніздувалися тут. Знищення евтрофних боліт та пов'язаних з ними осокових і осоково-хвощових формацій позбавило гніздового біотопу Acrocephalus paludicola.

Тотальна заміна відкритих просторів із лучною та степовою рослинністю на полях 3 монокультурою у поєднанні з браконьєрством спричинили зникнення Otis tarda, Tetrax tetrax та Melanocorypha calandra.

Втрата природних степових ділянок та водно-болотних угідь позначилась і на пролітних птахах нині трапляються під час міграцій Netta rufina, Clangula hyemalis, Anthropoides virgo та Glareola nordmanni. Ti ж птахи, що раніше гніздували у водно-болотних комплексах $[1 ; 7 ; 8 ; 11]$, наразі трапляються лише під час міграції: Anas clypeata, Pandion haliaetus, Circus macrourus, Circaetus gallicus, Falco cherrug, Falco naumanni, Haematopus ostralegus, Tringa ochropus, Tringa glareola, Phylomachus pugnax, Numenius arquata, Sterna albifrons, Coracias garrulus та Anthus pratensis.

Рідкісними зальотними птахами досліджуваної території останнім часом є Aquila clanga та Falco peregrinus.

Істотно скоротила популяцію хижих птахів усіх видів кампанія зі скорочення чисельності Accipiter gentilis, Accipiter nisus та Circus aeruginosus, яку здійснювали у 50-х роках ХХ ст. Через високі темпи зведення старих лісів зникли Milvus milvus, Aquila heliaca, які гніздувалися тут раніше, a Aquila chrysaetos та Haliaeetus albicilla нині лише зрідка трапляються під час зальотів та зимівлі. Тотальне вирубування старих борів призвело до зникнення 3 меж Поділля й окремих дрібних горобцеподібних птахів, зокрема Regulus ignicapillus.

Варто відзначити ще цілу низку видів птахів, чиї регулярні або спорадичні зальоти на територію Подільського Побужжя орнітологи реєстрували на початку XX ст., а наразі жодних достовірних 
даних про їх перебування на Вінниччині або Хмельниччині немає. Це, зокрема, Ardeola ralloides, Tadorna tadorna, Rufibrenta ruficollis, Netta rufina, Stercorarius parasiticus, Surnia ulula, Melanocorypha leucoptera, Luscinia megarhynchos, Parus cyanus та Calcarius lapponicus.

Окремі дослідники фауни минулих років [7; 11] припускали можливість гніздування Circus macrourus та Circaetus gallicus, але в сучасних зведеннях даних про їх гніздування на Поділлі немає.

Поява великих площ незамерзаючих водойм, зокрема охолоджувачів електростанцій, сприяє формуванню потужних зимувальних скупчень водоплавних і навколоводних птахів. Це дало змогу чималій кількості видів птахів - і гніздовим перелітним, і мігруючим - залишатись на зимівлю. Це, зокрема, Anas platyrhynchos, Bucephala clangula, Aythya marila, Mergus albellus, Mergus serrator, Mergus merganser та Fulica atra.

Варто також зауважити, що завдяки розширенню меж гніздових ареалів орнітофауна Подільського Побужжя збагатилася шістьма видами птахів, які на початку минулого століття класифікувались як пролітні: Phalacrocorax carbo, Cygnus olor, Aythya fuligula, Aythya marila, Larus canus та Turdus pilaris.

Ще 13 видів птахів, яких раніше відмічали лише під час зальотів або відомостей про їх перебування на Поділлі не було, сьогодні можна спостерігати на гніздуванні або під час міграцій. Такими птахами є: Egretta alba, Egretta garzetta, Anser erythropus, Phasianus colchicus, Tringa stagnatilis, Himantopus himantopus, Larus argentatus, Larus cachinnans, Streptopelia decaocto, Dendrocopos syriacus, Motacilla citreola, Phoenicurus ochruros, Serinus serinus.

Окремі види 3'явилися у фауні досліджуваного регіону в результаті акліматизації. У деяких мисливських господарствах Середнього Побужжя була здійснена спроба інтродукції Ph. colchicus. Наразі ці птахи відмічені на гніздуванні у Чечельницькому районі Вінницької області.

Поява окремих видів птахів на південному сході Поділля пов'язана 3 процесами розширення меж гніздових частин ареалів. Це, зокрема, E. alba, E.garzetta, L. cachinnans, S. decaocto, D.syriacus, M.citreola, Ph.ochruros, S.serinus. Варто зазначити, що активна експансія більшості зазначених видів та поява їх на Поділлі спостерігалася у 40-60-х роках XX ст. [9].

Ще три види птахів, які не спостерігались на початку минулого століття на Поділлі, ми виявили у долині Південного Бугу. Це, зокрема, Melanitta nigra, Sturnus roseus та Parus cristatus.

Так, на ділянці природного річища Південного Бугу в околицях м. Вінниці в останній декаді лютого 2008 р. ми відмітили дві особини M.nigra. Відзначимо, що це перше спостереження представників цього виду на Поділлі. Інвазія $M$. nigra у досліджуваний регіон можлива 3 північно-західної Європи або зимівель на Чорноморському узбережжі.

У публікації В. О. Новака та Л. М. Новак [6] також можна знайти відомості про факти зальотів у верхів'я Південного Бугу таких видів, як Falco rusticolus, Phalaropus lobatus, Numenius phaeopus, Larus ichthyaetus, Hydroprogne caspia.

3 кінця XX ст. у верхів'ях Південного Бугу В. О. Новак зафіксував зальоти ще деяких видів птахів, яких ми у 2000-2014 роках не виявили. Такими видами є Melanitta fusca та Charadrius hiaticula [5; 6].

У міграційний період В. О. Новак [5] виявив на прольоті також Anser erythropus, Buteo rufinus, Falco cherrug, Falco naumanni та Larus melanocephalus.

Решта представників орнітофауни (186 видів) антропогенних ландшафтів Подільського Побужжя упродовж останнього століття не змінили свого статусу перебування на цій території, натомість відбулися зміни в численності їх популяцій.

Висновки та перспективи подальшого дослідження. За даними власних досліджень та публікаціями інших орнітологів встановлено, що на початку XXI ст. орнітофауна антропогенних ландшафтів Верхнього і Середнього Побужжя об'єднує 246 видів птахів, які належать до 18 рядів, 53 родин і 134 родів.

За статусом перебування у межах дослідженої території переважають гніздові (110 видів, 45,3 \%) та осілі (50 видів, 20,6 \%) птахи, які за своїм фауністичним походженням належать до восьми типів. Найчисленнішими є європейські (81 вид, 47,9 \%) та транспалеарктичні (44 види, 26 \%) види.

Під дією антропогенної трансформації природних екосистем, прямого та опосередкованого впливу на птахів упродовж останнього століття структура авіфауни регіону зазнала змін. Так, 22 види птахів зникли з меж досліджуваної території, а 36 - змінили свій статус перебування на ній. Натомість 21 вид птахів був зареєстрований тут уперше, з них сім видів упродовж означеного терміну розширили свою гніздову частину ареалу на значні площі, зокрема й на досліджену територію. 


\section{Джерела та література}

1. Герхнер В. Ю. Матеріяли до вивчення птахів Поділля / В. Ю. Герхнер // Труди фізично-математичного відділу. - Т.VI. - Вип. 3. - К., 1928. - С. 131-192.

2. Колякина Н. Н. Специфика городской орнитофауны / Н. Н. Колякина // Поволж. экол. вестн. - 2005. № 11. - С. 275-279.

3. Матвійчук О. А. Орнітофауна Верхнього і Середнього Побужжя / О. А. Матвійчук, В. В. Серебряков. К. : Фітосоціоцентр, 2010. - 280 с.

4. Микитюк А. Ю. ІВА программа. Методические рекомендации по организации учета птиц / А. Ю. Микитюк. - К. : Укр. о-во охраны птиц, 1997. - 31 с.

5. Новак В. О. Матеріали по фенології міграцій птахів на Поділлі. 1. Non-Passeriformes / В. О. Новак // Авіфауна України. - 2002. - Вип. 2. - С. 73-86.

6. Новак В. О.Орнітофауна Хмельницької області (фауністична характеристика) / В. О. Новак, Л. М. Новак. - Хмельницький, 1998. - 30 с.

7. Носаченко А. В. Орнитофауна окрестностей Погребища (Винницкая область) в 1918-1921 гг. / А. В. Носаченко // Авіфауна України. - 2008. - Вип. 4. - С. 6-49.

8. Портенко Л. А. Очерк фауны птиц Подольской губернии / Л. А. Портенко // Бюл. Моск. об-ва испыт. природы. Секция биологов. - 1928. - № XXXVII. - Ч. І. - С. 92-198.

9. Птахи України під охороною Бернської конвенції / [заг. ред. Г. Г. Гаврись]. - К., 2003. - 394 с.

10. Фесенко Г. В. Анотований список українських наукових назв птахів фауни України / Г. В. Фесенко, А. А. Бокотей. - К. ; Львів, 2002. - 44 с.

11. Храневич В. Птахи Поділля : огляд систематичний / В. Храневич. - Вінниця, 1925. - 66 с.

12. Штегман Б. К. Основы орнитогеографического деления Палеарктики / Б. К. Штегман. - М. ; Л. : Изд-во AH CCCP, 1938. - 157 c.

Матвийчук Александр. Ретроспективная оценка орнитофауны Подольского Побужья. В статье освещены структурные изменения в видовом составе орнитофауны отдельных территорий Винницкой и Хмельницкой областей, принадлежащих к бассейну р. Южный Буг. В период с 2000-го по 2014 год установлено пребывание в границах исследуемой территории 243 видов птиц, принадлежащих к 19 отрядам, 53 семействам и 132 родам. По характеру пребывания на территории Подольского Побужья доминируют гнездящиеся (110 видов, 45,3\%) и оседлые (50 видов, 20,6 \%) птицы, принадлежащие к восьми типам фаунистического происхождения. Наиболее многочисленными оказались европейские виды (81 вид, 47,9\%) и транспалеаркты (44 вида, 26 \%).

Установлено, что под влиянием антропогенной трансформации природных экосистем, прямого и косвенного влияния хозяйственной деятельности человека на птиц в течение XX века структура авифауны региона существенно изменилась. Так, 22 вида птиц исчезли с исследуемой территории, а 36 - сменили свой статус пребывания на ней. В то же время 21 вид птиц был зарегистрирован здесь впервые, из них семь видов в течение последнего столетия расширили свою гнездовую часть ареала на значительные площади, в том числе и на территорию Подольского Побужья.

Ключевые слова: орнитофауна, Подольское Побужье, антропогенная трансформация, фаунистическое происхождение, видовой состав.

Matviichuk Oleksandr. Retrospective Evaluation of the Avifauna of the Podolsky Pobuzhzhia. The article highlights the structural changes in the species composition of the avifauna of individual territories Vinnytsia and Khmelnytsky regions belonging to the pool of Yuzhny Bug river. In the period from 2000 to 2014 found staying within the boundaries of the study area 243 species of birds belonging to 19 orders, 53 families and 132 genera. On the territory of the Podolsky Pobuzhzhia dominate breeding (110 species, 45,3\%) and sedentary (50 species, 20,6\%) birds that belong to the 8 species of fauna origin. The most numerous were the European species $(81$ species, $47,9 \%)$ and transpalearktic species (44 species, $26 \%$ ).

It was found that under the influence of anthropogenic transformation of natural ecosystems, direct and indirect effects of human activities on birds exerted during the twentieth century, the structure of the region's avifauna has changed significantly. For example, 22 bird species have disappeared from the study area, and 36 have changed their residence status on it. At the same time, 21 species of birds were recorded here for the first time, including 7 species over the last century have expanded their range into the socket significant areas, including the territory of the Podolsky Pobuzhzhia.

Key words: avifauna, Podolsky Pobuzhzhia, anthropogenic transformation, faunal origin, species composition.

Стаття надійшла до редколегії 27.02.2015 p. 